\title{
Ethanol from lignocellulosic biomass
}

\author{
Diana Abril ${ }^{1}$, and Alejandro Abril ${ }^{2}$ \\ 'Universidad Católica del Maule, Instituto de Ciencias Básicas. San Miguel 3605, Talca, Chile. \\ ${ }^{2}$ Unión de Investigación-Producción de la Celulosa del Bagazo Cuba-9, Habana, Cuba.
}

\begin{abstract}
D. Abril, and A. Abril. 2009. Ethanol from lignocellulosic biomass. Cien. Inv. Agr. 36(2):177-190. Ethanol is the liquid combustible that has become the most promising alternative substitute for gasoline because of the experience gained in its production, the possibility of mixing it with gasoline in different proportions, the possibility of using the existing gasoline distribution infrastructure, and the fact that major changes in engines are not required for its use. Lignocelluloses offer great potential as a biomass source for ethanol production, although their use still requires in-depth analysis with an objective and holistic focus that includes present and future technologic implications. The present article reviews current knowledge about the characteristics and sources of vegetable biomass, as well as the development and possibilities for obtaining ethanol from lignocellulosic sources.
\end{abstract}

Key words: Alcoholic fermentation, energy, ethanol, lignocellulosic ethanol, vegetable biomass.

\section{Introduction}

The development of technological society is closely linked to humankind's growing energy needs. Fossil fuels, namely oil, natural gas and coal, have been the fundamental sources of energy during the 20 th and early $21^{\text {st }}$ centuries. At the same time, they have been increasingly used as raw materials for chemical industries (Rojas, 2006).

Presently, we may see that the end of oil exploitation is near. Therefore, future energy generation, as well as fundamental sources of raw materials, will come to rely more and more on renewable sources.

Vegetal biomass is a renewable source of energy, chemical products and other materials,

Received 16 April 2008. Accepted 18 August 2008. Corresponding author: dabril@ucm.cl resulting from the conversion of solar energy by plant photosynthesis. As the end of the "oil age" draws nearer, biomass will play an important role in becoming the base of new industries in the near future (Abril, 2008).

Several alternatives exist for the progressive replacement of fossil fuels. In addition to fuels from biomass, these include hydraulic energy, eolic energy, nuclear energy, and solar energy (direct and photovoltaic). There is also the possibility of obtaining energy commercially from ocean tides (Castro, 2003). The need to improve efficiency in generating and conserving energy must be also considered along with these alternative strategies.

In the case of biomass exploitation, ethanol $\left(\mathrm{CH}_{3}-\mathrm{CH}_{2}-\mathrm{OH}\right)$ is presently the most well developed possible liquid fuel substitute for gasoline. A wealth of experience has been acquired for obtaining ethanol from biomasses. It is possible to mix it with gas in different proportions, without 
making great changes in currently used engines, and the existing infrastructure for gas distribution may be used for delivery (Abril, 2006).

The advances and possibilities in metabolic engineering, such as the development of microorganisms and appropriate enzymes for obtaining ethanol from lignocellulosic materials, are reviewed in Zaldivar et al. (2001).

In this literature article, the main characteristics of lignocellulosic biomass, its exploitation and current possibilities for obtaining ethanol, as well as the main processes employed for this purpose are reviewed.

\section{Lignocellulosic biomass}

Biomass of lignocellulosic origin is the most abundant source of organic material on Earth. It comes from forests, agricultural and forest cultivation, harvest, forestry and industrial residues, and cellulose and recycled paper (Billa, 1993). Lignocellulosic materials result from plant photosynthesis which converts solar energy to organic material, with the benefit of being both biodegradable and renewable. With this approach, the use of lignocellulosic biomass as fuel represents a sustainable and environmentally-friendly method of solar energy exploitation (Dey and Brinson, 1984).

Lignocellulosic biomass consists of cellulose, hemicellulose, lignin, organic extractives (mixture of different organic compounds) and some inorganic components, which turn into ash following combustion (Wiselogel et al., 1996). Cellulose, hemicellulose and lignin, constitute more than $75 \%$ of the vegetal material, and are composed of organic polymers of high molecular weight.

\section{Energy exploitation of biomass and carbon dioxide emissions}

The burning of fossil fuels releases large amounts of carbon dioxide $\left(\mathrm{CO}_{2}\right)$ into the atmosphere, which is foreign to the atmospheric cycle, but pertinent to the geological cycle. Conversely,
$\mathrm{CO}_{2}$ emitted by biomass combustion (residual or not), comes from the atmosphere and returns to it. Therefore, substitution of fossil fuels by biomass does not produce additional $\mathrm{CO}_{2}$ emissions, but has a slightly $\mathrm{CO}_{2}$ capturing effect, as not all $\mathrm{CO}_{2}$ utilized by plants returns to the atmosphere through combustion. Such is the case of tree roots and other cultivations, which are not used as energy resources (Broder et al., 1992). During biomass combustion, the generation of nitrogen oxides (NOx) is usually very low. Due to the small amount of sulfur in the composition, the amount of sulfur dioxide $\left(\mathrm{SO}_{2}\right)$ released in biomass combustion is also below the most strict control levels (Claassen et al., 1999).

The most potentially problematic products of biomass combustion are fine particulates (PM10), volatile organic compounds (VOCs) and toxic substances (in urban solid residues) (Cardona et al., 2004). PM10s may be reduced using appropriate filters or by electrostatic precipitation. VOCs are responsible of ozone formation, in presence of appropriate light and temperature. All of these emissions may have negative consequences on human health and ecosystems.

Methane $\left(\mathrm{CH}_{4}\right)$, originating from landfills, anaerobic digestion by cattle residues, residual waters, and their release to the atmosphere, contributes significantly to the greenhouse effect. Likewise, if agricultural and forest residues were burnt under the open sky, PM10s, VOCs and organic compounds would be released to the atmosphere in ten times greater quantities than if they were burnt in a power plant.

A small, permanent proportion of agricultural residues in soil is known to provide a higher capacity of nutrients retention and water, in addition to a slight reduction in erosion. However, the presence of too many residues in soil may lead to decreased productivity as soil temperature decreases. Agricultural residues also reduce nitrate formation, and may host microorganisms that may cause infections in future harvests.

Direct and indirect advantages of energy exploitation of biomass include: (i) restriction of agricultural activities to rural zones, preserv- 
ing their specific characters, (ii) elimination of agricultural subsides, (iii) restoration of ecosystems, (iv) decrease in rural exodus of human populations to urban centers, (v) energy production and generation in the countryside, returning direct benefits on economy, including the generation of tax revenue, (vi) development of technologies and the creation of new industries, and (vii) decrease of vulnerability of the fuel supply (Lynd, 2003).

\section{Obtaining ethanol from lignocellulosic materials}

Due to its chemical composition, lignocellulosic biomass differs greatly from products with high sugar or starch content (Galbe and Zacchi, 1993; Galbe et al., 1997; McMillan, 1997). The input/ output relation between the energy released during ethanol combustion and the energy needed to produce it from lignocellulosic residues is six, a little lower than the process using sugars and honeys, but quite superior than the process using grains (Van Zessen et al., 2003).

Cellulose and hemicelluloses must first be hydrolyzed to simple sugars and then fermented to ethanol (Cowling and Kirk, 1976). Fermentation of hydrolyzed glucose from cellulose is an established process. However, fermentation of hydrolyzed hemicellulose pentoses currently presents some technical and economical difficulties (Cowling, 1975; Thompson, 1983; Wilkie, 1979).

Lignin is source of a large amount of aggregate value products, as well as a feasible source of energy which could be used to cover energy demands of an ethanol plant, from biomass and other products (Triana, 1990). However, lignin is a polyphenol that cannot be fermented to ethanol as extractives and other present components (Kira et al., 1977; Nimz et al., 1981; Wallace, 1989; Van Soest, 1982). As such, lignin introduces a negative effect on the fermentative processes; therefore, any viable process for obtaining ethanol from lignocellulosic biomass must include lignin extraction and its exploitation in obtaining valued products and/or energy generation (Adler, 1977). This situation creates an additional problem, as a process for manu- facturing several products requires a secure market in order to avoid unwanted accumulations or create a new residual (Szczodrak and Fiedurek, 1996).

The process of obtaining ethanol has to be adjusted according to the characteristics and properties of the biomass components and, in general, requires several industrial stages (Bothast, 1999; Gardner, 1974). The general method used to obtain ethanol from lignocellulosic biomass consists of the following steps: pre-treatment of the biomass, hydrolysis, fermentation and distillation (Zaldivar et al., 2001).

\section{Pre-treatment}

Pre-treatment consists of the collection, transportation, manipulation, storage, grinding or chipping to reduce the particle size and opening the fibrous material in order to transform it into a suspension that may be pumped and enable the further penetration of the chemical hydrolysis agents (Muzzy et al., 1983). It also includes a thermalchemical treatment, in order to achieve soften lignin and hemicelluloses to enable the further action of enzymes or microorganisms (Millett et al., 1975). According to Lynd (1996), a pretreatment process must ideally meet the following requirements: (i) produce reactive fibers, (ii) separate the pentoses without degradation, (iii) not generate compounds inhibiting fermentation, (iv) net require a dramatic reduction of particle size, (v) use reactors of reasonable size and moderate cost, (vi) not generate solid residuals, and (vii) be simple and effective at low humidity.

Table 1 lists the methods proposed for pretreatment of lignocellulose biomasses (Sun and Cheng, 2002). A method to improve the degradation stage of lignocellulose in the process of obtaining ethanol consists of treating the material with ultrasound, which reduces the requirement of cellulase, the enzyme constituting the most expensive element in this process, between $33 \%$ and 50\% (USA Patent 6333181). These physical and physical-chemical pre-treatment steps are intended to disintegrate the matrix, i.e., reduction of cellulose to the maximum the degree of crystallinity and increasing amorphous cellu- 
Table 1. Methods used for the pre-treatment of lignocellulosic biomass to obtain ethanol.

\begin{tabular}{|c|c|c|c|c|}
\hline Methods & Procedure & Observations & Examples & References \\
\hline \multicolumn{5}{|l|}{ Physical } \\
\hline $\begin{array}{l}\text { Mechanic } \\
\text { Pulverization }\end{array}$ & ground & $\begin{array}{l}\text { Ball mills }(0.2 \text { to } \\
2.0 \mathrm{~mm}), \text { knives or } \\
\text { hammers }(3.0 \text { to } 6.0 \\
\mathrm{mm})\end{array}$ & $\begin{array}{l}\text { Wood residues, corn, } \\
\text { sugar cane bagasse, } \\
\text { straw }\end{array}$ & Sun and Cheng, 2002 \\
\hline Pyrolysis & $\mathrm{T}>3000 \mathrm{C}$ & $\begin{array}{l}\text { Hydrolysis with } \\
\mathrm{H} 2 \mathrm{SO} 41 \mathrm{~N}, 970 \mathrm{C} 2.5 \\
\text { h of the residues }\end{array}$ & $\begin{array}{l}\text { Woods and cotton } \\
\text { residues }\end{array}$ & Yu and Zhang, 2003. \\
\hline \multicolumn{5}{|l|}{ Physical-Chemical } \\
\hline Steam Explosion & $\begin{array}{l}\text { Saturated steam } \\
\text { at } 160-260^{\circ} \mathrm{C} \text {, } \\
\text { pressure of } 0.7- \\
4.9 \mathrm{MPa} \text { in short } \\
\text { periods, followed by } \\
\text { decompression. }\end{array}$ & $\begin{array}{l}80 \% \text { hemicelluloses } \\
\text { hydrolysis and some } \\
\text { cellulose. Formation } \\
\text { of fermentation } \\
\text { inhibitors. The use of } \\
\mathrm{SO}_{2}, \mathrm{H}_{2} \mathrm{SO}_{4} \text { or } \mathrm{CO}_{2}, \\
\text { diminishes inhibitors } \\
\text { formation. }\end{array}$ & $\begin{array}{l}\text { Woods, sugarcane } \\
\text { bagasse, rice straw. }\end{array}$ & $\begin{array}{l}\text { Sun y Cheng 2002; } \\
\text { Söderström et al. } \\
\text { 2003; Lynd et al. } \\
2002 \text {. }\end{array}$ \\
\hline $\begin{array}{l}\text { Liquid } \\
\text { hot } \\
\text { water } \\
\text { (LHW) }\end{array}$ & $\begin{array}{l}\text { Water } 170-2300 \mathrm{C} \text {, at } \\
\text { pressure, } 1-46 \mathrm{~min} \text {. }\end{array}$ & $\begin{array}{l}80 \% \text { hemicelluloses } \\
\text { Hydrolysis and some } \\
\text { cellulose. Solids } \\
\text { Concentration }<20 \%\end{array}$ & Sugar cane bagasse & $\begin{array}{l}\text { Laser et al. } 2002 . \\
\text { Lynd et al. } 2002 .\end{array}$ \\
\hline
\end{tabular}

lose, which is the most appropriate substrate for further enzymatic treatment.

In the next stage, the cellulose released is subject to an enzymatic hydrolysis with exogen cellulases, which results in a solution of fermentable sugars, mainly glucose, but also pentoses resulting from the initial hydrolysis of hemicellulose. These sugars are converted to ethanol through the action of microorganisms that are able to ferment the sugars present in the pre-treated and hydrolyzed lignocellulosic material. The pre-treatment increases the yield of cellulose hydrolysis from less than $20 \%$ of the theoretical yield to values higher than $90 \%$ (Lynd, 1996).

Steam explosion is the most commonly used method for the pre-treatment of lignocellulosic materials (McMillan, 1994). In this method, appropriately prepared biomass is subjected to steam at high temperature and pressure. Subsequently, a fast decompression is carried out, which causes the explosion of the cellular tissue and separation of components to a certain extent, enabling further hydrolysis (Sun and
Cheng, 2002). Addition of sulfuric acid $\left(\mathrm{H}_{2} \mathrm{SO}_{4}\right)$, $\mathrm{SO}_{2}$ and $\mathrm{CO}_{2}$ improves the hydrolysis reaction (Morjanoff and Gray, 1987). Steam explosion consumes $70 \%$ less energy than mechanical treatments (Holtzapple et al., 1989). The main disadvantage is the formation of fermentation inhibitors (Mackie et al., 1985).

Another pre-treatment process is ammonia fiber explosion (AFEX). In this process, the material is subjected to liquid $\mathrm{NH}_{3}$ at high temperature and pressure, and a subsequent fast decompression, similar to the steam explosion, which causes a fast sacarification of the lignocellulosic material (Mes-Hartree et al., 1988; Tengerdy and Nagy, 1988; Holtzapple et al., 1991; Holtzapple et al. 1992; Reshamwala et al. 1995; Vlasenko et al., 1997). The ammonia breaks down the cellulose crystallinity (Mitchell et al., 1990; Gollapalli et al., 2002). This process does not generate fermentation inhibitors (Dale et al., 1984; MesHartree et al., 1988), nor does it require small size particles (Holtzapple et al., 1990). Another advantage of this process is the possibility of recycling ammonia, due to its volatility (Wyman et al., 2005a). 
Explosion with carbon dioxide $\left(\mathrm{CO}_{2}\right)$ is also used. The yield in this case is lower than the above methods, but higher than enzymatic hydrolysis without pre-treatment (Dale and Moreira, 1982; Zheng et al. 1998).

Ozone $\left(\mathrm{O}_{3}\right)$ may be also used for the pre-treatment of lignocellulosic materials (Ben-Ghedalia and Miron, 1981; Ben-Ghedalia and Shefet, 1983; Neely, 1984; Vidal and Molinier, 1988). Pre-treatment with ozone has the advantage of being carried out at room temperature and atmospheric pressure, and does not generate fermentation inhibitors (Vidal and Molinier, 1988).

Concentrated acids have also been used, for example $\mathrm{H}_{2} \mathrm{SO}_{4}$ and hydrochloric acid $(\mathrm{HCl})$. However, these methods have the disadvantage of being toxic and corrosive. In addition, they must be retrieved to make the process economically viable (Sivers and Zacchi, 1995).

Diluted acids have been satisfactorily used for pre-treatment. Diluted sulfuric acid allows high reaction speeds and significantly improvement in cellulose hydrolysis (Esteghlalian et al., 1997; Lloyed and Wyman, 2005; Wyman et al., 2005b). The economy of this process is also improved through increased hydrolysis of hemicelluloses, which constitute a third of the material carbohydrates (Hinman et al., 1992). In general, there are two types of pretreatments with diluted acids: high temperature $\left(>160^{\circ} \mathrm{C}\right)$ continuous processes with low solid content (5-10\%) (Converse et al., 1989) and discontinuous low temperatures $\left(<160^{\circ} \mathrm{C}\right)$ processes with high content of solids (10-40\%) (Esteghlalian et al., 1997). Studies by Liu and Wyman $(2003,2004)$, showed that an increase in flow speed improves the removal of hemicelluloses and lignin in pre-treatments with pressurized hot water or well-diluted sulfuric acid at high temperatures.

The results of pre-treatments with alkalis depend on the lignin content of the material (McMillan, 1994), which change the porosity of the material (Tarkow and Feist, 1969). Lignin also causes a decrease crystallinity, breakage of links between lignin and carbohydrates, and breaks in the lignin structure (Fan et al., 1987). Regard- less the advantages, these methods present difficulties from the point of view of the process economy for obtaining fuels (Hsu, 1996).

Lignin biodegradation may be catalyzed with the enzyme peroxidase in presence of hydrogen peroxide $\left(\mathrm{H}_{2} \mathrm{O}_{2}\right)$ (Azzam, 1989). For example, pre-treatment of sugar cane bagasse (residual matter obtained after extraction of the juice) with $\mathrm{H}_{2} \mathrm{O}_{2}$ significantly improves its susceptibility to enzymatic hydrolysis (Bjerre et al., 1996).

Filamentous fungi have been used for biological degradation of lignin and hemicellulose in lignocellulosic materials (Fan et al., 1987; Waldner et al., 1988; Boominathan and Reddy, 1992; Jacobsen and Wyman, 2002; Nagle et al., 2002).

\section{Hydrolysis}

Hydrolysis may be catalyzed by acids, bases, heat and with help of microorganisms. This is intended to transform the viscose mass obtained in the previous stage into a solution of oligomeric sugars. These oligomeric sugars are then converted into monomeric sugars, hexoses (glucose) and pentoses (xylose).

Pre-treatment and acid hydrolysis are the most widely used in industrial processes and have the advantage of separating monomeric sugars from hemicelluloses, and expose cellulosic fibers to further hydrolytic action (Farone and Cuzens, 1996a). Nevertheless, as a disadvantage, it generates some fermentation inhibitor compounds; therefore a detoxification step is needed (Farone and Cuzens, 1996b). Inhibitor substances are formed as a result of hydrolysis of the different components, of esterified organic hemicellulose acids, and the solubilized phenolic lignin derivatives. Inhibitors are also formed from degradation products of soluble sugars and lignin (Lynd, 1996; Palmqvist and Hahn-Hägerdal, 2000a,b). Therefore, depending on the type of pre-treatment and hydrolysis used, it is essential to carry out a detoxification step prior to fermentation. 


\section{Fermentation}

Fermentation is carried out in order to ferment monomeric sugars (glucose and xylose) into ethanol. Enzymatic treatments are preferable to the chemicals ones. (Zaldivar et al., 2001). The following fermentation options are considered.

Separated hydrolysis and fermentation (SHF). This process has the disadvantage that glucose accumulation inhibits the cellulase activity as a result of hydrolysis.

Simultaneous sacarification and fermentation (SSF), using cellulases from external sources. This process has a faster hydrolysis and high yield, requires a smaller enzyme load and reduces the risk of contamination. A compromise between the operation temperature and the total speed of the process is needed, as the hydrolysis step is slower than fermentation. An adaptation of the SSF process is already patented and is known as the Gulf SSF process (Gauss et al., 1976).

Separated sacarification and fermentation. In this process, microorganisms also produce cellulase by direct microbial conversion. It has the disadvantages of a low ethanol yield, caused by the formation of by-products, low tolerance of the microorganisms to ethanol, and the limited growth of hydrolyzed syrup.

Distillation. This process includes three stages: production of raw ethanol (45\%), rectification (96\%) and dehydration at (99.9\%).

\section{Some commercial processes for ethanol production from lignocellulosic biomass}

The commercial processes for obtaining ethanol from lignocellulosic biomass are based on acid hydrolysis processes, from which hemicellulose and cellulose solubilization may be obtained where the lignin content remains unaltered (Wayman and Parekh, 1990). Some processes used in ethanol production from lignocellulosic biomass are based on modifications of the Gulf SSF process (Ingram et al. 1997). In general, these processes use Escherichia coli strains for fermentation.
Lignin is extracted from the solid fraction and may be used as fuel in industrial plants. Cellulose is hydrolyzed to glucose with commercial cellulase, and is fermented with Saccharomyces cerevisiae. Klebsiella oxytoca $\mathrm{P} 2$, bacteria requiring a lower amount of cellulase, may be used to decrease the enzyme cost. Preliminary economic evaluations have calculated that the cost of ethanol production using E. coli KO11, in a pentose-rich substrate, would be $0.48 \mathrm{USD} / 1$ (Von Sivers et al., 1994).

A process based on the use of Zymomonas mobilis using lignocellulose obtained from hard woods (McMillan et al., 1999) consists of $i n$ situ cellulase production to enable simultaneous sacarification and fermentation. The cost estimated for ethanol obtained by this process is 0.36 USD per liter. In the future, it is estimated that prices of 0.11 USD per liter may be obtained with advances in metabolic engineering (Wooley et al., 1999).

In 1989, the Centro de Investigaciones Energéticas, Medioambientales y Tecnológicas (CIEMAT) in Spain started an investigation program focused on obtaining yeast strains able to produce ethanol with good yields at temperatures higher than $40^{\circ} \mathrm{C}$. As result of this work using chemical mutagenesis, a mutant strain of Kluyveromyces marxianus has been obtained, which allows ethanol yields higher than 50\% (Ballesteros, 1998).

\section{Metabolic engineering of microorganisms for converting lignocellulose to ethanol}

Metabolic engineering is defined as "the improvement in the formation of products or cell properties, through the modification of specific biochemical reactions or the introduction of new reactions through recombinant DNA technologies" (Stephanopoulos, 1998; Bailey, 1991). The essential and desired requirements for microorganisms to be used in lignocellulosic biomass fermentation are shown in Table 2. A special emphasis is placed on the creation of efficient microorganisms for this process by metabolic engineering, due to the lack of a suitable microorganism for the efficient fermentation of lignocellulosic substrates (Hahn-Hägerdal et al., 1994; 
Chandrakant and Bisaria 1998). The organisms with the greater potential and where the greatest efforts have been made are S. cerevisiae, Z. mobilis and E. coli (Yu and Zhang, 2003).

Table 2. Essential and desired requirements of microorganisms for fermentation

\begin{tabular}{ll}
\hline Essential requirements & Requested requirements \\
\hline Wide range of substrates & Act on different sugars \\
High yield and productivity on ethanol & Hydrolyze cellulose and hemicelluloses \\
Minimum formation of by-products & GRAS Status \\
High tolerance to ethanol & Recyclable \\
High tolerance to inhibitors & Minimum nutrients supplement \\
$\begin{array}{l}\text { Resistant to the medium (pH, ionic force, temp., ethanol } \\
\text { concentration) }\end{array}$ & Resistance to low pH and Highs temperatures \\
\hline
\end{tabular}

GRAS - Generally recognized as safe, FDA (USA).

Three approaches have been used to engineer xylose fermentation by these microorganisms, as xylose is the most common pentose in hemicelluloses. These are the insertion of bacterial xylose isomerase genes, the insertion of genes using pentoses of Pichia stipitis, and the improvement of the xylose consumption (pentose).

The insertion of bacterial xylose isomerase genes obtained from E. coli, Bacillus subtilis or Thermus thermophilus, has so far been ineffective in fermenting xylose. This has been attributed to different factors, such as the differences in the internal $\mathrm{pH}$ between the bacteria and the yeast (Sarthy et al., 1987; Amore et al., 1989, Zaldivar et al., 2001).

The insertion of XYL1 (xylose reductase) and XYL2 (xylitol dehydrogenase) genes of $P$. stipitis, allow $S$. cerevisiae to grow in xylose and produce low levels of ethanol (1.6 g. $\mathrm{L}^{-1}$ of ethanol per $21.7 \mathrm{~g} \cdot \mathrm{L}^{-1}$ of xylose), which is not sufficient for a economically viable process.

The improvement on xylulose consumption has been attempted by insertion of $S$. cereviciae genes and heterological genes of XYL1 and XYL2 of P. stipitis (Zaldivar et al., 2001) into a hybrid host obtained by the cultivation of $S$. uvarum and $S$. diastaticus, producing the Saccharomyces strain $1400 \mathrm{pLNH} 32$, which is able to grow in xylose with a theoretical yield of $66 \%$. However, the yield obtained from xylitol was still high. Another strain obtained Saccharomyces 1400 pLNH33, was able to grow in glucose and xylose, but was unstable in a non-selective medium (Zaldivar et al., 2001). Other modifications, such as chromosomal integration, resulted in creation of the strain $\mathrm{Sac}$ charomyces 1400 LNH-ST, which can grow in xylose and glucose mixtures with yields of $70 \%$ in a continuous two stage process (Zaldivar et al., 2001).

The current approach to improve pentose conversion by $S$. cerevisiae is the insertion of genes for the arabinose metabolism and xylose transporter. Yeasts are a good source of genes for arabinose, e.g., Candida aurigiensis, and $P$. stipitis for the transporter of xylose.

The second ethanologenic microorganism, $Z$. mobilis, which is widely used in beverage production, ferments at $\mathrm{pH} 5$ and between 30 and $40^{\circ} \mathrm{C}$. It has a theoretical yield of $97 \%$. The strategy of inserting genes allowing the use of xylose and arabinose is used to extend the spectrum of fermentable substrates. By this procedure, strains like Z. mobilis CP4 (pZB5), ATCC 39676 (pZB186) and 206C (pZB301) have been obtained, which able to ferment xylose and arabinose with high yields $(>80 \%)$ (Zaldivar et al., 2001). The use of $Z$. mobilis genetically modified by the integration of six genes which allow fermentation of pentoses and glucose simultaneously from lignocellulosic biomass have been described (Shi-Zhong, 2006). Modified $Z$. mobilis has the advantages of requiring a minimum of nutrients, growing at low $\mathrm{pH}$ and high temperatures, and it is considered gener- 
ally recognized as safe (GRAS). A comparison of modified Z. mobilis and E. coli showing their respective advantages is shown in Table 3 .

The main strategy to increase the ethanol production from $E$. coli is by redirecting the carbon flow towards ethanol production, through the insertion of $Z$. mobilis genes, as well as others (Zaldivar et al., 2001).

Table 3. Comparison between modified Zymomonas mobilis and Escherichia coli

\begin{tabular}{lll}
\hline & $\begin{array}{l}\text { Zymomonas } \\
\text { mobilis }\end{array}$ & Echerichia coli \\
\hline Ethanol, $\mathrm{g} \cdot \mathrm{L}^{-1}$ & 62 & 27 \\
Ethanol yield ${ }^{1} \%$ & 97 & 90 \\
Productivity, $\mathrm{g} \cdot \mathrm{L}^{-1} \mathrm{~h}^{-1}$ & 1.29 & 0.92 \\
\hline
\end{tabular}

${ }^{1}$ Estimation from the theoretical yields.

Another important consideration in improving the fermentation process is increasing the tolerance of microorganisms to fermentationinhibiting compounds. The amount and the type of inhibitors present depend on the source of lignocellulose, process conditions and other factors (Clark and Mackie, 1984; Buchert, et al., 1990; Buchert and Niemella 1991; Palmqvist et al., 1996; Larsson et al., 1997,1999; Taherzadeh et al., 1997b; Stenberg et al., 1998; Palmqvist and Hahn-Hägerdal, 2000a,b). The inhibitors generated may come from the degradation of sugars (pentoses furfural, hexoses hydroxymethylfurfural), organic acids by degradation or oxidation, lignin derivatives and inorganic impurities (Fengel, 1984; Ranatunga, 2000).
Inhibitors affect the general cell physiology, decreasing their capacity for ethanol generation. In the case of $S$. cerevisiae, inhibition is mainly caused by furans (Palmqvist et al., 1999a; Taherzadeh et al., 2000), aliphatic acids (Taherzadeh et al., 1997a, Palmqvist et al., 1999b) and aromatic compounds (Ando, 1986; Larsson et al., 2000). The inhibitor effect on Z. mobilis CP4 (pZB5) by some aliphatic and aromatic compounds (Ranatunga, 1997), and on E. coli KO11 Y LY01 (Zaldivar et al., 1999, 2000) have has also been studied.

\section{Conclusions}

Bioethanol production from lignocellulosic biomasses represents a great potential alternative source of fuel. This is especially important considering the ongoing energy crisis. In addition, the availability and renewability of lignocellulosic biomasses represent a real advantage over fossil fuels. Many different technologies to obtain ethanol from lignocellulosic biomass are in different degrees of development and industrial scaling. In general, and because of the structural characteristics of lignocellulosic materials, technologies are developed in several stages, including pretreatment, hydrolysis and fermentation. Pretreatment is fundamental to enable a further hydrolysis and fermentation processes, which may be carried out through different chemical processes and products.

\section{Resumen}

D. Abril y A. Abril. 2009. Etanol a partir de biomasa lignocelulósica. Cien. Inv. Agr. 36(2):177-190. El etanol es un combustible líquido que debido a la experiencia de producción existente se ha convertido en una importante alternativa para sustituir el uso de gasolina. Es posible mezclarlo en diferentes proporciones con gasolina, los motores no requieren de mayores cambios para su empleo y para su distribución es posible emplear la infraestructura existente para la gasolina. El uso de lignocelulosas como biomasa parece promisoria para la producción de etanol, aun cuando debería aun se analizado cuidadosamente con el propósito holístico que incluya todas la tecnologías actuales y sus posibles implicancias. En este artículo se revisa el conocimiento de las características y fuentes de biomasa de origen vegetal, como también el desarrollo, características y posibilidades de obtener etanol de fuentes lignocelulósicas.

Palabras clave: Biomasa vegetal, energía, etanol, etanol liognocelulósico, fermentación alcholica. 


\section{References}

Abril, A. 2006. Etanol Lignocelulósico. Monografía. Unión de Investigación-Producción de la Celulosa del Bagazo, Cuba-9 y CYTED (Cooperación Iberoamericana), Ciudad Habana, Cuba.

Abril, A. 2008. Etanol. aditivo o alternativa para el combustible automotor. I Taller Nacional de Etanol Celulósico. ICIDCA, Habana, Cuba.

Adler, E. 1977. Lignin chemistry - past, present and future. Wood Sci. Technol. 11:169-218.

Amore, R., M. Wilhelm, and C.P. Hollenberg. 1989. The fermentation of xilose- an analysis of the expression of Bacillus and actino planes xylose isomerase genes in yeast. Appl. Microbiol. Biotechnol. 30:351-357.

Ando, S., I. Arai, K. Kiyoto, and S. Hanai. 1986. Identification of aromatic monomers in steamexploded poplar and their influence on ethanol fermentation by Sacharomyces cerevisiae. J. Ferment. Technol. 64:567-570.

Azzam, A.M. 1989. Pretreatment of cane bagasse with alkaline hydrogen peroxide for enzymatic hydrolysis of cellulose and ethanol fermentation. J. Environ. Sci. Health 24:421-433.

Ballesteros, I. 1998. Desarrollo Rural y Energías Renovables. Biomasa y Biocombustibles. Proyecto: Combustibles Líquidos. CIEMAT. Madrid, España.

Bailey, J.E. 1991. Towards a science of methabolic engineering. Science 252:1668-1674.

Ben-Ghedalia, D., and J. Miron. 1981. The effect of combined chemical and enzyme treatment on the saccharification and in vitro digestion rate of wheat straw. Biotechnol. Bioeng. 23:823-31.

Ben-Ghedalia, D., and G. Shefet. 1983. Chemical treatments for increasing the digestibility of cotton straw. J Agric Sci.100:393-400.

Billa, E., B. Monties, and C. Choudens. 1993. Silica and phenolic acid derivatives in wheat straw and corresponding high yield pulps. Paper No. 4. In: Conf. Proc. Straw-a valuable raw material, Cirencester, UK

Bjerre, A.B., A.B. Olesen, and T. Fernqvist. 1996. Pretreatment of wheat straw using combined wet oxidation and alkaline hydrolysis resulting in convertible cellulose and hemicellulose. Biotechnol. Bioeng. 49:568-77.

Boominathan, K., and C.A. Reddy. 1992. cAMP-mediated differential regulation of lignin peroxidase and manganese dependent peroxidase produc- tion in the white-rot basidiomycete Phanerochaete chrysosporium. Proc. Natl. Acad. Sci., USA. 89:5586-5590.

Broder, J.D., J.W. Barrier, and G.R. Lightsey. 1992. Conversion of cotton trash and other residues to liquid fuel. Pages 189-200. In: Liquid Fuels from Renewable Resources: Proceedings of an Alternative Energy Conference. J.S. Cundiff, J.S. (ed.). American Society of Agricultural Engineers, St. Joseph, MI, USA.

Buchert, J., and K. Niemella. 1991. Oxydative detoxification of word-derived inhibitors by $\mathrm{Glu}$ conobacter oxydans. Biotechnology 18:103-116.

Buchert, J., K. Niemella, J. Puls, K. Poutanen. 1990. Improvement in the fermentability of steamed hemicellulose hydrolisate by ion exclusion. Proc Biochem Int 25:176-180.

Cardona, C., O. Sánchez, J. Ramírez, and L. Alzate. 2004. Biodegradación de residuos orgánicos de plazas de mercado. Rev. Col. Biottecnol. 6:7889.

Castro Díaz-Balart, F. 2003. Hacia un Desarrollo Sostenible en la Era de la Globalización Ciencia, Tecnología y Sociedad. Editorial Científico-Técnica, La Habana, Cuba. P.19-21.

Chandrakant, P., and V.S. Bisaria. 1998. Simultaneous bioconversion of cellulose and hemicellulose to ethanol. Crit. Rev. Biotechnol. 18:295-331.

Claassen, P.A.M., J.B. van Lier, A.M. López, E.W. J. van Niel, L. Sijtsma, A.J.M. Stams, S.S de Vries, and R.A. Weusthuis. 1999. Utilisation of biomass for the supply of energy carriers. Appl. Microbiol. Biotechnol. 52:741-755.

Clark, T.A., and K.I. Mackie. 1984. Fermentation inhibitors in wood hydrolysates derived from the softwood Pinus radiata. J. Chem. Technol. Biotech. 34:101-110.

Converse, A.O.K., I.K. Warteng, H.E. Grethlein, and H. Ooshima. 1989. Kinetics of thermochemical pretreatment of lignocellulosic materials. Appl. Biochem. Biotechnol. 20/21:63-78.

Cowling, E.B. 1975. Physical and chemical constraints in the hydrolysis of cellulose and lignocellulosic materials. Biotechnol. Bioeng. Symp. 5:163-181

Cowling, E.B., and Kirk, T.K. 1976. Properties of cellulose and lignocellulosic materials as substrates for enzymatic conversion processes. Biotechnol. Bioeng. Symp. 6:95-123.

Dale, B.E., and M.J. Moreira. 1982. A freeze-explosion technique for increasing cellulose hydrolysis. Biotechnol. Bioeng. Symp. 12:31-43. 
Dale, B.E., L.L. Henk, and M. Shiang. 1984. Fermentation of lignocellulosic materials treated by ammonia freeze-explosion. Dev. Ind. Microbiol. 26:223-233.

Dey, P.M., and K. Brinson. 1984. Plant cell walls. Adv. Carb. Chem. Biochem. 42:265-282.

Esteghlalian, A., A.G. Hashimoto, J.J. Fenske, and M.H. Penner. 1997. Modeling and optimization of the dilute sulphuric-acid-pretreatment of corn stover, poplar and switchgrass. Bioresour Technol. 59:129-36.

Fan, L.T., M.M., Gharpuray, and Y.H. Lee. 1987. Cellulose Hydrolysis Biotechnology Monographs, vol. 3. Springer. Berlin, Germany. 198 p.

Farone, W. A., Cuzens, J. E. 1996a. Method of Separating Acids and sugars Resulting from Strong Acid Hydrolysis. U.S. Patent No. 5,580,389.

Farone, W.A., and J.E. Cuzens. 1996b. Method of Producing Sugars Using Strong Acid Hydrolysis of Cellulosic and Hemicellulosic Materials. U.S. Patent No. 5,562,777.

Fengel, D., and G. Wegener.1984. Wood-chemistry, Ultraestructure Reactions. Walter de Gruyter. Berlin, Germany. 613 p.

Galbe, M., and G. Zacchi. 1993. Simulation processes for conversion of lignocelluloses. Pages 291-319. In: J.N. Saddler (ed.). Bioconversion of Forest and Agricultural Plant Residues. CAB International. Wallinford, UK.

Galbe, M., M. Larsson, K. Stemberg, C. Tenborg, and G. Zacchi. 1997. Ethanol from wood: Design and operation of a process development unit for technoeconomic process evaluation. Pages 110129. In: ACS Symposium Series 666. American Chemical Society, Washington DC, USA.

Gardner, K. H. and Blackwell. J. 1974. The hydrogen bonding in native cellulose. Bioch. Bioph. Acta. 343, 232-237.

Gauss, W. F., S. Suzuki, M. Takagi. 1976. Manufacture of alcohol from cellulosic material using plural fermenters. U.S. Pat. 3,990,94 gradation of lignin 4. USA.

Gollapalli, L.E., B.E. Dale, and D.M. Rivers. 2002. Predicting digestibility of ammonia fiber explosion (AFEX)-treated rice straw. Appl. Biochem. Biotechnol. 98-100:23-35.

Hahn-Hägerdal, B., H. Jeppsson, K. Skoog, and B. A. Prior. 1994. Biochemistry and physiology of xylose fermentation by yeast. Enzyme Microb. Technol. 16:933-943.

Hinman, N.D., D.J. Schell, C.J. Riley, P.W. Bergeron, and P.J. Walter. 1992. Preliminary estimation of the cost of ethanol production for SSF technology. Appl. Biochem. Biotechnol. 34/35:639-49.

Holtzapple, MT., A.E. Humphrey, and J.D. Taylor. 1989. Energy requirement for the size reduction of poplar and aspen wood. Biotechnol. Bioeng. 33:207-210.

Holtzapple, M.T., J.H. Jun, G. Ashok, S.L. Patibandla, and B.E. Dale. 1990. Ammonia fiber explosion (AFEX) pretreatment of lignocellulosic wastes. Proceedings of the American Institute of Chemical Engineers National Meeting. Chicago, IL, USA.

Holtzapple, M.T., J.H. Jun, G. Ashok, S.L. Patibandla, and B.E. Dale. 1991. The ammonia freeze explosion (AFEX) process: a practical lignocellulose pretreatment. Appl. Biochem. Biotechnol. 28/29:59-74.

Holtzapple, M.T., J.E. Lundeen, and R. Sturgis. 1992. Pretreatment of lignocellulosic municipal solid waste by ammonia fiber explosion (AFEX). Appl. Biochem. Biotechnol. 34/35: 5-21.

Hsu, T.A. 1996. Pretreatment of biomass. In: Wyman CE, editor. Handbook on bioethanol production and utilization. Applied. Energy Technology Series. Taylor and Francis. Washington, DC, USA.

Jacobsen, S.E., and C.E. Wyman. 2002. Xylose monomer and oligomer yields for uncatalyzed hydrolysis of sugarcane bagasse hemicellulose at varying solids concentration. Ind. Eng. Chem. Res. 41:1454-1461.

Kirk, T.K., W.J. Connors, and J.G. Zeikus. 1977. Advances in undertaking the microbiological degradation of lignin. Pages 369-394. In: F.A. Loewus, and V.C. Runeekles, (eds.) The Structure, Biosynthesis and Degradation of Wood. Plenum. NY, USA.

Larsson, S., M. Galbe, G. Zacchi, E. Palmqvist, and B. Hahn-Hägerdal. 1997. Recirculation of process water in the production of ethanol from softwood. Bioresourse. Technol. 60:143-151.

Larsson, S., E. Palmqvist, B. Hahn-Hägerdal, C. Tenborg, K. Stemberg, G. Zacchi, and N.O. Nilvebrant. 1999. The generation of inhibitors during dilute hydrolysis of softwood. Enzyme Microb. Technol. 24:151-159.

Larsson, S., A. Quintana-Sáinz, A. Reimann, N.O. Nilvebrant, and I. J. Jönsson. 2000. The influence of lignocellulose-derived aromatic compounds on oxygen-limited growth and ethanolic fermentation by Saccharoyices cerevisiae. Appl. Biochem. Biotechnol. 84/86:617-632.

Laser, M., D. Schulman, S.G. Allen, J. Lichwa, Jr. 
M.J. Antal, and L.R. Lynd. 2002. A comparison of liquid hot water and steam pretreatments of sugar cane bagasse for bioconversion to ethanol. Bioresour. Technol. 81:33-44.

Liu, C., and C.E. Wyman. 2003. The effect of flow rate of compressed hot water on xylan, lignin, and total mass removal from corn stover. Ind. Eng. Chem. Res. 42:5409-5416.

Liu, C., and C.E. Wyman. 2004. The effect of flow rate of very dilute sulfuric acid on xylan, lignin, and total mass removal from corn stover. Ind. Eng. Chem. Res. 86:88-95.

Lynd, L.R. 1996. Overview and evaluation of fuel ethanol from cellulosic biomass: technology, economics, the environment and policy. Annu. Rev. Energy Environ. 21:403-465.

Lynd, L.R. 2003. Cellulosic Ethanol Fact Sheet National Commission on Energy Policy Forum: The Future of Biomass and Transportation Fuels. Washington DC, USA.

Lynd, L.R, P.J. Weimer, W.H. van Zyl, and I.S. Pretorious. 2002. Microbial cellulose utilization: Fundamentals and biotechnology. Microbiol. Mol. Biol. Rev. 66:506-577.

Lloyed, T.A., and C.E. Wyman. 2005. Combined sugar yields for dilute sulphuric acid pretreatment of corn stover followed by enzymatic hydrolysis of the remaining solids. Bioresour. Technol. 96:1967-1977.

Mackie, K.L., H.H. Brownell, K.L. West, and J.N. Saddler. 1985. Effect of sulfur dioxide and sulphuric acid on steam explosion of aspenwood. J. Wood Chem. Technol. 5:405-425.

McMillan, J.D. 1994. Pretreatment of lignocelluloses biomass. Pages 292-324. In: M.E. Himmel, Baker, J.O., Overend, R.P. (eds.). Conversion of Hemicellulose Hydrolyzates to Ethanol. American Chemical Society Symposium. Washington DC, USA.

McMillan, J.D. 1997. Bioethanol production: Status and prospeets. Renewable Energy 10:295-302.

McMillan, J.D., M.M. Newman, D.W. Templeton, and A. Mohagheghi, 1999. Simultaneous saccharification and cofermentation of dilute-acid pretreated yellow poplar to ethanol using xylose fermenting Zymomonas mobilis. Appl. Biochem. Biotechnol. 77-79:649-665.

Mes-Hartree, M, B.E. Dale, and W.K. Craig. 1988. Comparison of steam and ammonia pretreatment for enzymatic hydrolysis of cellulose. Appl. Microbiol. Biotechnol. 29:462-468.

Millett, M.A., A.J. Baker, and L.D. Satter. 1975. Pre- treatments to enhance chemical, enzymatic and microbiological attack of cellulosic materials. Biotechnol. Bioeng. Symp. 5:193-219.

Mitchell, D.J., K. Grohmann, M.E. Himmel, B.E. Dale, and H.A. Schroeder. 1990. Effect of the degree of acetylation on the enzymatic digestion of acetylated xylans. J. Wood Sci. Technol. 10:111-121.

Morjanoff, P.J., and P.P. Gray. 1987. Optimization of steam explosion as method for increasing susceptibility of sugarcane bagasse to enzymatic saccharification. Biotechnol. Bioeng. 29:733-741.

Muzzy, J.D., R.S. Roberts, C.A. Fieber, G.S. Faass, and T.M. Mann. 1983. Pretreatment of hardwood by continuous hydrolysis. Pages 351-368. In: J. Soltes (ed.). Wood and Agricultural Residues. Academic Press. NY, USA.

Nagle, N.J., R.T. Elander, M.M. Newman, B.T. Rohrback, R.O. Ruiz, and R.W. Torget. 2002. Efficacy of a hot washing process for pretreatment yellow poplar to enhance bioethanol production. Biotechnol. Prog. 18:734-738.

Neely, W.C. 1984. Factors affecting the pretreatment of biomass with gaseous ozone. Biotechnol. Bioeng. 20:59-65.

Nimz, H.H., D. Robert, O. Faix, and M. Nemi. 1981. Carbon13 NMR spectra of lignins, 8. Structural differences between lignins of hardwoods, grasses and compression wood. Holzforschung 35:16-26.

Palmqvist, E., and B. Hahn-Hägerdal. 2000a. Fermentation of lignocellulosic hydrolysates. I: inhibition and detoxification. Bioresour. Technol. 74: 17-24.

Palmqvist, E., and B. Hahn-Hägerdal. 2000b. Fermentation of lignocellulosic hydrolysates. II: inhibitors and mechanisms of inhibition. Bioresour. Technol. 74: 25-33.

Palmqvist, E., B. Hahn-Hägerdal, M. Galbe, and G. Zacchi. 1996. The effect of water soluble inhibitors from steam-pretreated willow on enzymatic hydrolysis and ethanol fermentation. Enzyme Microbiol Technol 19:470-476.

Palmqvist, E., J. S. Almeida, and B. Hahn-Hägerdal 1999a. Influence of furfural on anaerobic glycolytic kinetics of $S$. cerevisiae in bath culture. Biotechnol Bioeng 62:447-454.

Palmqvist, E., H. Grage, N.Q. Meinander, and B. Hahn-Hägerdal. 1999b. Main and interaction effects of acetic acid, furfural and p-hydroxybenzoic acid on growth and ethanol productivity of yeast. Biotech Bioeng 63:46-55. 
Ranatunga, T.D., J. Jarvis, R.F. Helm, J.D. Mc Millan, and C. Hatzis. 1997. Identification of inhibitor components toxic towards Z. mobilis CP4 (pZB5) xylose fermentation. Appl. Biochem. Biotechnol. 67:185-198.

Ranatunga, T.D., J. Jarvis, R.F. Helm, J.D. Mc Millan, R.J. Wooley. 2000. The effect of overliming on the toxicity of dilute acid pretreated lignocellulosics: The role of inorganics, uronic acids and other soluble organics. Enzyme Microb. Technol. 27: 240-247.

Reshamwala, S., B.T. Shawky, and B.E. Dale. 1995. Ethanol production from enzymatic hydrolysis of AFEX-treated coastal Bermuda grass and switchgrass. Appl. Biochem. Biotechnol. 51/52:43-55.

Rojas, O. 2006. Biorefinerías y Materiales a Partir de Biomasa. Universidad del Estado de Carolina del Norte EUA. Conferencia Magistral Congreso Iberoamericano de Investigaciones en Celulosa y Papel. Valdivia. Chile.

Sarthy, A.V., B. McConanughty, Z. Lobo, and J.A. Sundstrom, C.E. Fulong, and B.D. Hall. 1987. Expression of Escherichia coli xylose isomerase gene in Saccharomyces cerevisiae. Appl. Environ. Microbiology. 53:1996-2000.

Shi-Zhong, L. 2006. Engineered Bacteria for Ethanol Production from Lignocellulose Center for Biomass Engineering China Agricultural University. Beijing, China

Söderström, J., L. Pilcher, M. Galbe, and G. Zacchi. 2003. Two-step steam pretreatment of softwood by dilute $\mathrm{H}_{2} \mathrm{SO}_{4}$ impregnation for ethanol production. Biomass Bioenerg. 24:475-486.

Stenberg, K., C. Tenborg, M. Galbe, G. Zacchi, E. Palmqvist, and B. Hahn-Hägerdal. 1998. Recycling of process streams in ethanol production from softwoods based on enzymatic hydrolysis. Appl. Biochem. Biotechnol. 70/72: 697-708.

Stephanopoulus, G., A.A. Aristidou, and J. Nielsen. 1988. Metabolic Engineering-principles and Methodologies. Academic Press, San Diego, CA, USA. 725 pp.

Sun, Y., and J. Cheng. 2002. Hydrolysis of lignocellulosic material for ethanol production: a review. Bioresour. Technol. 83:1-11.

Szczodrak, J., and J. Fiedurek. 1996. Technology for conversion of lignocellulosic biomass to ethanol. Biomass and Bioenergy. 10:367-375.

Taherzadeh, M.J., C. Niklasson, and G. Liden. 1997a. Acetic acid-friend or foe in anaerobic batch conversion of glucose to ethanol by $S$. cerevisiae? Chen. Eng. Sc. 52:2653-2659.
Taherzadeh, M.J., R. Eklund, L. Gustafsson, C. Niklasson, and G. Liden. 1997b. Characterization and fermentation of dilute-acid hydrolyzates from wood. Ind. Eng. Chem. Res. 36:4659-4665.

Taherzadeh, M.J., L. Gustafsson, and G. Liden. 2000. Physiological effects of 5-hydroxymethylfurfural on S. cerevisiae. Appl. Microbiol. Biotechnol. 53:701-708.

Tarkow, H., and W.C. Feist. 1969. A mechanism for improving the digestibility of lignocellulosic materials with dilute alkali and liquid $\mathrm{NH}_{3}$. Pages 197-218. In: Advance Chemistry Series 95. American Chemical Society. Washington DC, USA.

Tengerdy, R.P., and J.G. Nagy. 1988. Increasing the feed value of forestry waste by ammonia freeze explosion treatment. Biol. Wastes 25:149-53.

Thompson, N.S. 1983. Hemicelulose as a biomass resource. Pages 101-119. In: J. Soltes (ed). Wood and Agricultural Residues. Academic Press, NY. USA.

Triana, O. 1990. Atlas Anatómico y Morfológico del Bagazo de Caña. GEPLACEA Serie: Diversificación, GEPLACEA/PNUD. Habana, Cuba.

van Zessen, E., M. Weismann, R.R.C. Bakker, H.W. Elbersen, J.H. Reith, H. den Uil. 2003. Lignocellulosic-ethanol, a second opinión.. Energy Research Center of the Netherland, ECN. Utrecht, The Netherlands.

van Soest, P.J. 1994. Nutritional Ecology of the Ruminants. Second ed. Cornell University Press. Ithaca, NY, USA. 498 p.

Vidal, P.F., and Molinier, J. 1988. Ozonolysis of lignin-improvement of in vitro digestibility of popular sawdust. Biomass 16:1-17.

Vlasenko, E.Y., H. Ding, J.M. Labavitch, and S.P. Shoemaker. 1997. Enzymatic hydrolysis of pretreated rice straw. Bioresour. Technol. 59:109119.

Von Sivers, M., G. Zacchi, L. Olsson, and B. HahnHägerdal. 1994. Cost analysis of ethanol from willow using recombinant E. coli. Biotechnol. Prog. 10:555-560.

Waldner, R., M.S.A. Leisola, and A. Fiechter. 1988. Comparison of lignolytic activities of selected fungi. Appl. Microbiol. Biotechnol. 29:400-407.

Wallace, G. 1989. A study of phenolic-carbohydrate linkages in the gramineae. $\mathrm{PhD}$ thesis. University of Glasgow. UK.227 pp.

Wayman, M., and S.R. Parekh. 1990. Biotechnology of Biomass Conversion. Fuels and Chemicals from Renewable Resources. Prentice Hall. USA. $278 \mathrm{pp}$. 
Wyman, C.E., B.E. Dale, R.T. Elander, M. Holtzapple, M.R. Ladisch, and Y.Y. Lee. 2005b. Comparative sugar recovery data from laboratory scale application of leading pretreatment technologies to corn stover. Bioresour Technol 96:2026-2032.

Wyman, C.E., B.E. Dale, R.T. Elander, M. Holtzapple, M.R. Ladisch, and Y.Y. Lee. 2005a. Coordinated development of leading biomass pretreatment technologies. Bioresour Technol. 96:19591966.

Wilkie, K.C.B. 1979. The hemicelluloses of grasses and cereals. Adv. Carb. Chem. Biochem. 36:215264.

Wiselogel, A., J. Tyson, and D. Johonsson. 1996. Biomass feedstock resources and its composition. Pages 105-118. In: C.E. Wyman (ed). Handbook of Biothanol: Production and Utilization. Taylor and Francis. Washington, DC, USA.

Yu, Z., and H. Zhang. 2003. Pretreatments of cellulose pyrolysate for ethanol production by Saccharomyces cerevisiae, Pichia sp. YZ-1 and Zymomonas mobilis. Biomass Bioenerg. 24:257-
262.

Zaldivar, J., and L.O. Ingram. 1999. Effect of organic acid son the growth and fermentation of ethanogenic E. coli LY01. Biotechnol. Bioeng. 66:203210.

Zaldivar, J., A. Martínez, and L.O. Ingram. 1999. Effect of selected aldehydes on the growth and fermentation of ethanogenic E. coli. Biotechnol Bioeng. 65:24-33.

Zaldivar, J., A. Martínez, and L.O. Ingram. 2000. Effect of alcohol compounds found in hemicellulose hydrolysate on the growth and fermentation of ethanogenic E. coli. Biotechnol Bioeng. 68:524-530.

Zaldivar, J., J. Nielsen, and L. Olsson. 2001. Minireview fuel ethanol production from lignocellulose: a challenge for metabolic engineering and process integration. App Microbiol Biotechnol 56:17-34.

Zheng, Y.Z., H.M. Lin, and G.T. Tsao 1998. Pretreatment for cellulose hydrolysis by carbon dioxide explosion. Biotechnol. Prog. 14:890-896. 
